\title{
Biyolojik Tanıma Elemanlarından Proteinoidler Kullanılarak Empedans Ölçüm Yaklaşımıyla Bakterilerin Tespiti
}

\section{Determination of Bacteria by Impedance Measurement Approach Using Proteinoids from Biological Recognition Elements}

\author{
Asiye Gök Yurttaş ${ }^{1 *}$
}

Geliş / Received: 08/06/2021

Revize / Revised: 15/09/2021

Kabul / Accepted: 29/09/2021

\section{$\overline{\mathbf{O Z Z}}$}

Günümüz dünyasında gelişen teknoloji ile su, gıda ve çevresel kirliliğin artmasıyla bu temel ihtiyaçların sağlık kontrolü oldukça zorlayıcıdır. Bu tür eksiklerin giderilmesi üzerine bir çalışma olmuştur. Bu amaçla iki temel aşamalı bir iş planı oluşturulmuştur. Birincisi; hedef bakteriye seçici tepki veren biyomoleküllerden olan proteinoidler sentezlenip karakterize edilmiş̧ir. Şuana kadar kullanılan biyolojik tanıma elemanlarından ilk defa farklı olarak proteinoidler bu çalışma ile kullanılmıştır. İkinci aşamada ise proteinoidler, yayılım gösteren bakterileri seçici olarak algılayarak elektriksel empedans ile fiziksel parametrelerde değişime neden olarak bioelektrik dönüşümü sağlanmasıdır. Dönüştürücü (transducer) içerisinde elektriksel karakterizasyon yöntemleri ile bakteri uyarımlarında teşhis başarımı elde edilmiş̧ir.

Anahtar Kelimeler-Proteinoid, Antibakteriyel, Biyobozunur, Biyoelektronik, Empedans

\begin{abstract}
In today's world, with the developing technology and the increase in water, food and environmental pollution, the health control of these basic needs is quite challenging. There has been a study on the elimination of such deficiencies. For this purpose, a two-stage business plan was created. First; Proteininoids, which are biomolecules that react selectively to target bacteria, were synthesized and characterized. Unlike the biological recognition elements used up to now, proteinoids were used in this study for the first time. In the second stage, proteinoid selectively detects spreading bacteria and cause a change in electrical impedance and physical parameters, thereby providing bioelectric transformation. Diagnostic performance in bacterial stimulation was achieved with electrical characterization methods in the transducer.
\end{abstract}

Keywords- Proteinoid, Antibacterial, Biodegradable, Bioelectronic, Impedance

1*Sorumlu yazar iletișim: asiye.yurttas@istun.edu.tr (https://orcid.org/0000-0002-6424-7411) Biyokimya Bölümü, İstanbul Sağllk ve Teknoloji Üniversitesi, Eczacllık Fakültesi, İstanbul, Türkiye 


\section{GíRiş}

Günümüzde güncel gelişmelere rağmen yaygın mevcut teknolojiler ile ortamdaki patojen analizi ortamdan numune alınarak yapılan laboratuvar testlerinin değerlendirilmesi ile yapılmakta, bu yöntem hem zaman hem de büyük bir milli gelir kaybına yol açmaktadır. Bu yöntemler çoğu karmaşık, pahalı, zayıf seçiciliğe sahip ve tekdüze prosedürler gerektirirler. Buna karşılık, elektrokimyasal yöntemlerin düşük maliyetli, basit, hassas olması ve çeşitli biyolojik türlerin seçici olarak belirlemesi ayrıca hızlı cevap süresi bu yöntemleri çekici kılmaktadır. Kimyasal olarak modifiye edilmiş elektrodların ortaya çıkması ile elektro analiz alanında hızlı iyileştirmeler sağlanmış, hassasiyet ve seçicilik için daha yüksek istekler karşılanmıştır [1]. Bu gelişmeler ile beraber yüksek performanslı biyoalgılayıcıların geliştirilmesi hızlı patojen tespiti için gerekli açığın kapatılmasını sağlayacaktır. Biyoalgılayıcılar, verilen örneklerden anlaşıldığı gibi yaşam kalitesini iyileştirmeyi amaçlayan çok geniş bir uygulama alanına sahiptir. Günümüzde hastalığın tanı, tedavisinde ve hastalığın ilerlemesini izleme, çevresel izleme, gıda kontrolü, gıda izlenebilirliği, kalitesi, güvenliği ve besin değerini izlemek, ilaç keşfi, adli tıp ve biyomedikal araştırmalar gibi birçok alanda kullanım alanları vardır [2-5] Biyoalgılayıcılarda çeşitli analitlere (patojen vd.) bağlanan biyolojik tanıma elemanları olarak; proteinler, aptamer, nükleik asit, bakteriler, metal iyonları, peptidler, enzimler ve antikorlar gibi biyomoleküller yaygınca kullanılmıştır [6-8]. Dolayısıyla patojenlerin yüksek seçicilikte algılanması için biyoduyargada seçilecek biyolojik tanıma elemanı önemlidir. Moleküler biyoduyargaların en önemli özellikleri yüksek seçicilik ve afinitedir. Bu çalışmada biyoduyargalar da kullanılan sistemlerden farklı olarak ilk defa proteinoid kullanıldı̆̆ 1 için özgündür. Proteinoidler (termal proteinler) kullanılan biyolojik tanıma elemanları içinde afinitesi ve seçiciliği en yüksek olanlardan biridir [9]. Bu sebeple bu çalışmada bakterileri algılaması için proteinoid kullanılacaktır. Proteinoidler en kısa tanımıyla ilkel proteinlerdir. Yüksek sıcaklığa maruz bırakılmış amino asitlerden oluşan bir grup sentetik, protein benzeri polimerden herhangi biridir [10,11]. Proteinoidler veya termal proteinler, çoğunlukla abiyotik olarak amino asitlerden oluşan çapraz bağlı moleküllerdir. İlk defa laboratuvar ortamında Sidney W. Fox tarafından oluşturulmuş ve canlı hücrelerin öncülü (protocells) olarak kabul edilmiştir. Proteinoidler ilaçlarda oral ilaçların paketlenip verileceği mikroskobik biyobozunur kapsüller, kanser teşhis ve tedavisinde, nanobiyotıp gibi alanlarda kullanılmıştır [12-14]. Bazik ve asidik proteinoidlerin elektriksel hareketleri, elektrik yüklerine ve bu proteinoidlerin taşıdığı amino asitlerin yüklerine bağlı olarak birbirleri arasında farklılık göstererek biyolojik uyumlulukları, toksik olmamaları nedeniyle birçok alanda kullanılmasını sağlamıştır [15,16].

Proteinoidler birçok aktiviteye sahiptir. Esteroliz, dekarboksilasyon, aminasyon, deaminasyon ve oksidoredüksiyon gibi katabolik enzim aktiviteleri bunların başında gelir. Ek aktivitelerinden bazı özellikleri ise hormonal aktivite gösterdiği gibi aynı zamanda hormonal aktiviteyi inhibe edicidir. ATP, peptidler veya oligonükleotitlerin oluşumu sentetik enzim aktiviteleridir. Proteinoid oluşumu ise, proteinoidlerin kendi aktivitesidir ve termal polimerizasyon sonucu rastgele oluşmaktadır [17]. Özetle birçok biyokimyasal aktiviteye sahip proteinodiler aynı anda bir hormon gibi ya da bir enzim veya bir antikor gibi davranabilir. Bu şekilde davranabilme özellikleri diğer biyolojik tanıma elemanlarının içinde kendisine yüksek afinite ve seçicilik katmaktadır. Aynı zamanda proteiniodlerin sentezlenme yöntemleri diğer biyolojik tanıma elamanlarına göre çok daha kolay ve ucuz olması, bu bileşikleri daha cazip kılmaktadır [18]. Proteinoidlerin biyolojik tanıma amacıyla bakterilerin belirlenmesi amacıyla kullanılması oldukça yeni bir uygulamadır ve bu çalışmanın özgünlüğünün en önemli kısmıdır.

\section{MATERYAL METOD}

\section{A. Proteinoid Sentezi ve Karakterizasyonu}

Belli oranlarda amino asitler alınarak azot gazı altında bir silikon yağ banyosunda karıştırıcılı ısıtıcıda üç boyunlu cam balonda reflüks edilerek ısıtıldı. Silikon yağı banyosunun sicaklığı, aminoasitler eriyik duruma gelene kadar aşamalı sıcaklık arttıralırak yükseltildi. Karışım azot gazı altında 12 saat ve $160{ }^{\circ} \mathrm{C}$ de sıcaklıkta karıştırıldı. Kahverengi macunsu kütlenin, reçinemsi sert bir kütleye dönene kadar oda sıcaklığında soğumaya bırakıldı. Daha sonra tortu, ağırlıkça $40 \mathrm{~mL}$, \% 10 sodyum bikarbonat çözeltisi ile ekstrakte edildi. Elde edilen polimer toz haline getirildi, bir desikatörde gece boyunca kurutuldu.

\section{B. Proteinoidlerin Mikroskop Görüntüleri}

Proteinoid ilk önce 1şık mikroskopta (Inverted Microscope, ZEISS AXIO) 20x büyütmede su ortamında görüntüler alındı. Floresan mikroskop, çoğunlukla yüksek duyarlılığı nedeniyle en sık kullanılan mikroskoplardandır. Boyama işlemi proteinoidlerin sentez aşamasından sonra gerçekleştirildi. Floresan mikroskop ile okunabilir etiketleme sağlayabilmek için en uygun boyama protokolu belirlendi. Görüntüleme için bir Floresan 
mikroskop (Fluorescence Inverted Microscope, ZEİSS AXIO) kullanıldı. Floresan boya çözeltileri hazırlandı ve proteinoidler ile etkileştirildi. Proteinoidler boyandıktan sonra, bağlanmayan boya polimerik partiküllerin süpernatantta boya kalmayana kadar distile suyla yıkanmasıyla ayrıldı. Şekil 2' de CD-138 ile boyanmış proteinoidlerin invert floresans mikroskop 50x büyütme ile görüntüleri alınmaktadır. Daha sonra SEM (Taramalı elektron mikroskop- JEOL JSM 7000F Field) görüntüleri aldı. Elektron mikroskobu içerdiği geri saçılan elektron görüntüsü ve ikincil elektron görüntüsü teknikleriyle malzemelerin yüzey ve kesitlerinin, yüksek büyütmelerde morfolojik ve kimyasal analizi için kullanılmaktadır.

\section{Proteinoidlerin Cyclic Voltammetry (CV) Deneyi}

Elektrolit çözeltisini elektrokatalitik ölçümlerde hazırlamak için ultra saf su ve sülfürik asit kullanıldı. Katalizör hazırlanmasında Vulcan XC-72 (VC) (Cabot Co.), \% 5 Nf çözeltisi (Aldrich), ekstra saf etil alkol (Merck) ve proteinoid bileşikleri kullanıldı. Pine Instruments'tan camsı karbon disk elektrodu, platin halka-camsı karbon disk elektrodu ve bu elektrotlar için bir cilalayıcı alındı. RRDE (halka-disk elektrot) ölçümleri, $25^{\circ} \mathrm{C}$ 'de yarı sabit koşullar altında ( $0.005 \mathrm{~V} 1$ tarama hızı) doymuş O2 altında $0.5 \mathrm{M} \mathrm{H} 2 \mathrm{~S} 04$ sulu çözeltisi içinde camsı bir karbon disk (5 mm çap) ile gerçekleştirildi. RRDE deneyleri için, çalışma elektrodu camsı bir karbon disk (5.61 $\mathrm{mm}$ çap) ve bir toplama verimliliğine ( $\mathrm{N}>\%$ 37) yol açan bir platin halkadır. Bu deneyler 2500 rpm'de doymuş oksijende gerçekleştirildi $25^{\circ} \mathrm{C}^{\prime}$ de $0.5 \mathrm{M} \mathrm{H} 2 \mathrm{~S} 04$ sulu elektrolit çözeltisi disk potansiyeli -0.1 Vs-1'de süpürüldü, halka potansiyeli SCE'ye karşı 0.8 V'de tutuldu. Katalizörleri RRDE deneyleri için bir karbon desteği üzerine dağıtmak amacıyla, $200 \mu \mathrm{L}$ mutlak etanol içinde $0.8 \mathrm{mg}$ proteinoid bileşiği, $1.2 \mathrm{mg} \mathrm{VC}$ ve ağırlıkça $10 \mu \mathrm{L} \% 5 \mathrm{Nf}$ çözeltisi karışımı hazırlandı ve yarım saat ultrasonik olarak homojenleştirildi. Her voltammogram, asidik ortamdaki olası katalizör bozunmasından dolayı yeni hazırlanmış bir elektrot ile kaydedildi. Karşı elektrot bir Pt spirandı ve referans elektrot bir SCE idi (Şekil 3).

\section{Bradford Protein Belirleme Deneyi}

Bradford belirteci(ayıraç, reagent) 1:4 oranında seyreltildi (1 ayırac, 4 dd su). BSA (Bovin serum albumin)' dan belli konsantrasyonlarda standartlar hazırlanıldı. BSA'nin lineer çalışma aralığ 0.2 ile $0.9 \mathrm{mg} / \mathrm{ml}$ 'dir. Örnek ve standart çözelti temiz tüpe pipetlenir daha sonra seyreltilmiş ayıraç üzerine eklendi ve karıştırıld. 10 dakika oda sıcaklığında beklendi. Biorad Smart Spektrofotometresi ile $595 \mathrm{~nm}$ 'de küvetlerle spektrometrik ölçüm yapıldı. Ölçümler üç kere tekrarlandı. Proteinoidin protein miktarı $0,450 \mathrm{mg} / \mathrm{ml}$ olarak bulundu. (Şekil 4).

\section{E. Proteinoidlerin Jel Geçirgenlik Kromatografi İle Molekül Ağırlık Grafiği (GPC)}

Jel geçirgenlik kromatografi (GPC) sistemi ile proteinoidlerin moleküler ağırlık dağılım ölçüm analizi yapılmıştır. Shimadzu Prominence GPC sistemi özellikle yüksek data güvenilirliği ile proteinoidlerin moleküler ağırlığı 312 dalton olarak bulundu (Şekil 5) .

\section{F. Proteinoidlerin Hücre Canlılığına Etkisi}

Proteinoidler kanser hücre hatlarında uygulanan hücre canlılığına olan etkileri farklı derişimlerinde MTT testi ile \% canlılık kontrolü yapıldı. Hücre canlılığının belirlenmesinde kullanılan MTT stabil bir tetrazolyum tuzu olup, canlı hücrelerde glikolitik yolakta üretilen $\mathrm{NAD}(\mathrm{P}) \mathrm{H}$ 'e bağımlı olarak indirgenir ve formazan kristallerinin oluşmasına sebep olur. Deney sonunda oluşan formazan kristali miktarı canlı hücre sayısı ile doğru orantılı olarak artar. Hücreler çoğaltılıp, sayıldıktan sonra 10000 hücre/kuyu olacak şekilde $100 \mu 1$ besiyeri/kuyu içeren 96 kuyucuklu plaklara ekildi ve 24 saat $37^{\circ} \mathrm{C}$ 'de kuyulara tutunmaları için inkübasyona bırakıldı. Ertesi gün proteinoidlerden hazırlanan ana stoklardan $0,12.5,25 \mathrm{ve} 50 \mu \mathrm{g} / \mathrm{ml}$ olacak şekilde etken maddeler hücrelere uygulandı. Bu maddelerin hücre canlılığına olan etkileri zamana bağlı olarak incelenmek üzere, ilaç uygulamasından 24 saatin sonunda MTT'dan $10 \mu \mathrm{l}$ eklendi. $37^{\circ} \mathrm{C}$ 'de 3 saat inkübasyona bırakıldı. İnkübasyon sonrasında hücre canlılığı spektrofotometre kullanılarak $540 \mathrm{~nm}$ 'de ölçüldü aşağıdaki formüle göre hesaplandı.

Canlılık $=($ Örnek540nm-Blank540nm $) /($ Control540nm-Blank540nm $)$

\section{G. Antimikrobiyal Madde Etkinliğinin Test Edilmesi (Agar Disk Difüzyon Yöntemi)}

Test mikroorganizmalarındanBL21 ve ER2508 E.colibakteri suşları daha önceden hazırlanan taze sıvı kültürü (18-24 saatlik) dökme plak yöntemiyle dökülmüştür. 1-1.5 cm çapındaki kağıt diskler (filtre kağıtlarından hazırlanmış)kapalı kapta otoklavda sterilize edildi. Her disk denenecek AMM'nin farklı dilüsyonuna ya da farklı bir AMM (antimikrobiyal madde) çözeltisine daldırıldı. Çözeltiyi absorblamış kağıt diskler test mikroorganizması aşılanmış agarlı besiyerinin yüzeyine yerleştirildi. Steril kağıt disklerden bir tanesi ise steril suya daldırılır ve kontrol olarak agarlı besiyeri yüzeyine yerleştirilir. Petri kutusu düz şekilde inkübatöre yerleştirilir ve test 


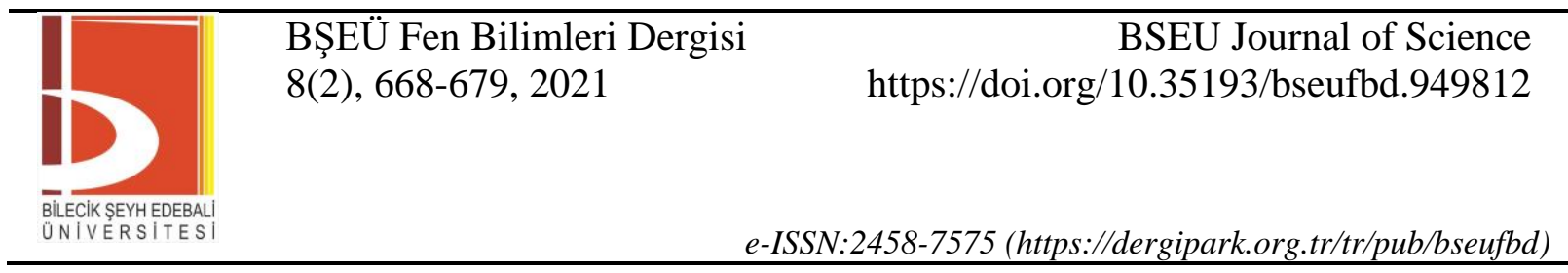

mikroorganizmasına uygun koşullarda inkübasyonu (örneğin $37^{\circ} \mathrm{C}$ 'de 22 saat) sağlanır. Şekil 7'de yapılan deneyde inhibisyon zonlan inkübasyonun 24. saatlerinde ayrı ayrı incelemeye alınarak değerlendirilmiş ve zon oluşmadığı görülmüştür. Kontrol amaçlı olarak yapılan ikinci deneyde iki plate hazırlanmıştır. Bu kontrol deneyin amacı çalışılan bakteri ya da kullanılan diğer malzemeden kaynaklı herhangi sorunun olmadığını garantilemektir. Birinin ağarına proteinoid emdirilerek sürülmüş iki ecoli bakterisi (BL21 ve ER2508 E-coli bakteri suşları) ekilmiştir. Diğer plate ise proteinoid sürülmeyerek yine aynı iki bakteri ekilmiştir. Bu deneyin sonucunda proteinoid ve kullanılan diğer malzemelerde herhangi bir sorun olmadığ 1 ve bakterilerinde sağlıklı bir şekilde çalışıldığı görülmüştür (Şekil 7).

\section{H. Elektrokimyasal Empedans Spektroskopi (EIS) Ölçümleri}

Empedans, ohm cinsinden ölçülen ve toprak öz direnci olarak nitelendirilen bir değerdir. Empedans ölçümü yapılarak, akım değişikliği belirlenir ve direnci artması ya da azalmasıyla maddenin ayırt edici özelliği belirlenir. Empedans, Z sembolüyle belirlenmekte ve Ohm cinsinden ölçülmektedir. Elektriksel empedans olarak tanımlanan özellik, aynı öz dirence sahip farklı maddelerin ayırt edilmesi için kullanılır. Kısaca empedansı, elektrik akımına karşı koyan faktör olarak tanımlayabiliriz. Yöntem: Jel matriks içerisinde serbest olarak proteinoid ile örnekler hazırlandı. Bunun en önemli nedeninin, jel içerisinde serbest bulunan proteinoidlerin entropi prensibine daha kolay uyum sağlayıp hareket edebileceği bir fiziksel ortam bulmaları olduğu düşünülmektedir. Jel matriks içerisinde serbest olarak bulunan proteinoidleri çevreleyen plakaların boyutları $(2 \mathrm{cmX} 2 \mathrm{cmx} 4 \mathrm{~mm})$ iki plaka arasındaki alana hacimce dağılmaktadır. Jel matriks ile çalışma koşullarından dolayı çok küçük plakaların kullanılması mümkün olmamıştır. Proteinoidler $50 \mu \mathrm{g} / \mathrm{ml}$ ve $100 \mu \mathrm{g} / \mathrm{ml}$ iki farklı derişimde hazırlandı. Proteinoidlerin çözücüsü olan distile suyu kontrol olarak kullanıldı. Proteinoidler $50 \mu \mathrm{g} / \mathrm{ml}$ ve $100 \mu \mathrm{g} / \mathrm{ml}$, distile, bakteri ve besiyeri sırasıyla jel matrikse eklenip faraday kafesinde empedans ölçümleri yapıldı (Şekil. 8). Deney sırasında empedans spektrometresinden (HF2IS /Zurich Instruments) alınan sonuçlar logaritmik ölçekte çizildi. İkinci aşamada ise; dönüştürücü (transducer) içerisinde elektriksel karakterizasyon yöntemleri ile bakteri uyarımlarında teşhis başarımı elde edilmeye çalışıldı. Teşhis başarımı tekrarlı olarak hedef başarım aralığı yakalanıncaya kadar karakterize eden işaret işlemi ve algoritması arasından uygunluk sağlamak üzere iyileştirmeler yapıldı.

\section{I. İstatistiksel Analiz}

Verilerin karşılaştırılması, Graphpad Instat (GraphPad Software, San Diego, CA, ABD) kullanılarak yapıldı. GraphPad Software yazılımı ile bir ANOVA tek yönlü testi hücre absorbans sayıları kullanılarak Sidak testi yapıldı. Tüm değerler tanımlayıcı istatistiklerde ortalama \pm SD olarak rapor edildi. T testi, verilerin Gauss dağılımlarını takip eden popülasyonlardan örneklendiğini varsayar. Bu varsayım, Kolmogorov ve Smirnov yöntemi kullanılarak test edilir. Eşleştirilmemiş iki değişkenin karşılaştırması, Welch düzeltmesi ile eşleştirilmemiş $t$ testi ile yapıldı. İkiden fazla parametrik olmayan değişkenin karşılaştırması Friedman Testi (Nonparametric Repeated Measures ANOVA) ile yapıldı ve bir post hoc testi için Dunn'ın Çoklu Karşılaştırma Testi kullanıldı.

\section{DENEYSEL BULGULAR}

\section{A. Proteinoidlerin Karakterizasyonu}

Preoteinoid sentezlendikten sonra FT-IR, H-NMR ve Uv-Vis ile karakterize edildi. Proteinoidlerin FTIR $\left(\mathrm{cm}^{-1}\right)$ spektrumları incelendiğinde $3299 \mathrm{~cm}^{-1}$ ve $3062 \mathrm{~cm}^{-1}$ de amid gerilim pikleri, $2956 \mathrm{~cm}^{-1} 2870 \mathrm{~cm}^{-1} \mathrm{de}$ alifatik $\mathrm{CH} 2$ pikleri, $1540 \mathrm{~cm}^{-1}$ amid CO piki, 1451 amid bükme $\mathrm{NH}$ pikleri ve $1666 \mathrm{~cm}^{-1}$ bu yapıya özgün $\mathrm{C}=\mathrm{O}-$ $\mathrm{OH}$ pikinin görülmesi kanıt niteliğindedir. Yapıya özgü tüm fonksiyonel grupların spektrumda görülmesi yapıyı doğrulamaktadır. Protenioidin H-NMR spektrumunda, 0.7 ppm - 0.9 ppm'de bulunan sinyaller Lösin kalıntısının metil grubuna aittir. 2.5 ppm - 2.8 ppm'deki sinyaller Lösin kalıntısının metilen grubuna bağlı protonların sinyallerine aittir. $3.4 \mathrm{ppm}-3.6$ ppm'deki sinyaller Aspartik asit'in metilen grubuna bağlı sinyaller ve $3.6 \mathrm{ppm}-$ 3.7 ppm'deki sinyal, amino asit kalıntılarının a işaretli karbonlarının protonlarından kaynaklanmaktadır. Aspartik asit kalıntısının sinyali ve Lösin kalıntısının sinyali spektrumda birlikte bulunduğundan, Proteinoidlerin başarıyla sentezlendiği düşünüldü. Uv spektrumunda iki ayrı pik $280 \mathrm{~nm}$ ve $380 \mathrm{~nm}$ de görülmüştür. 


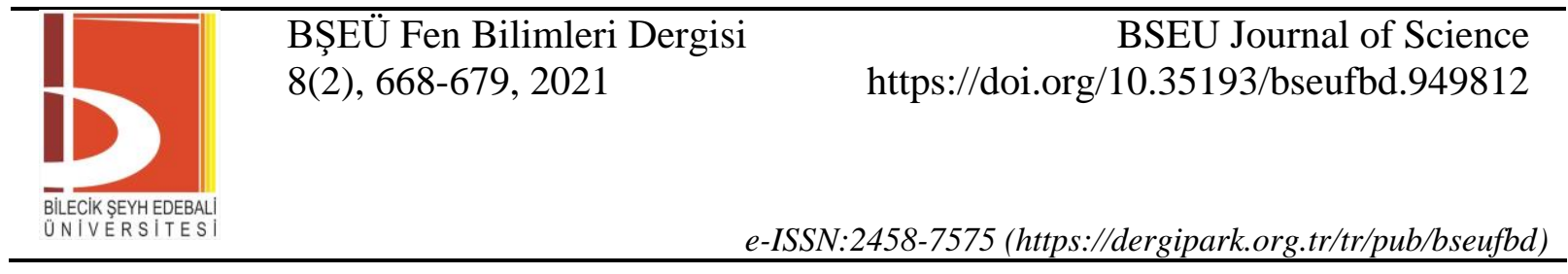
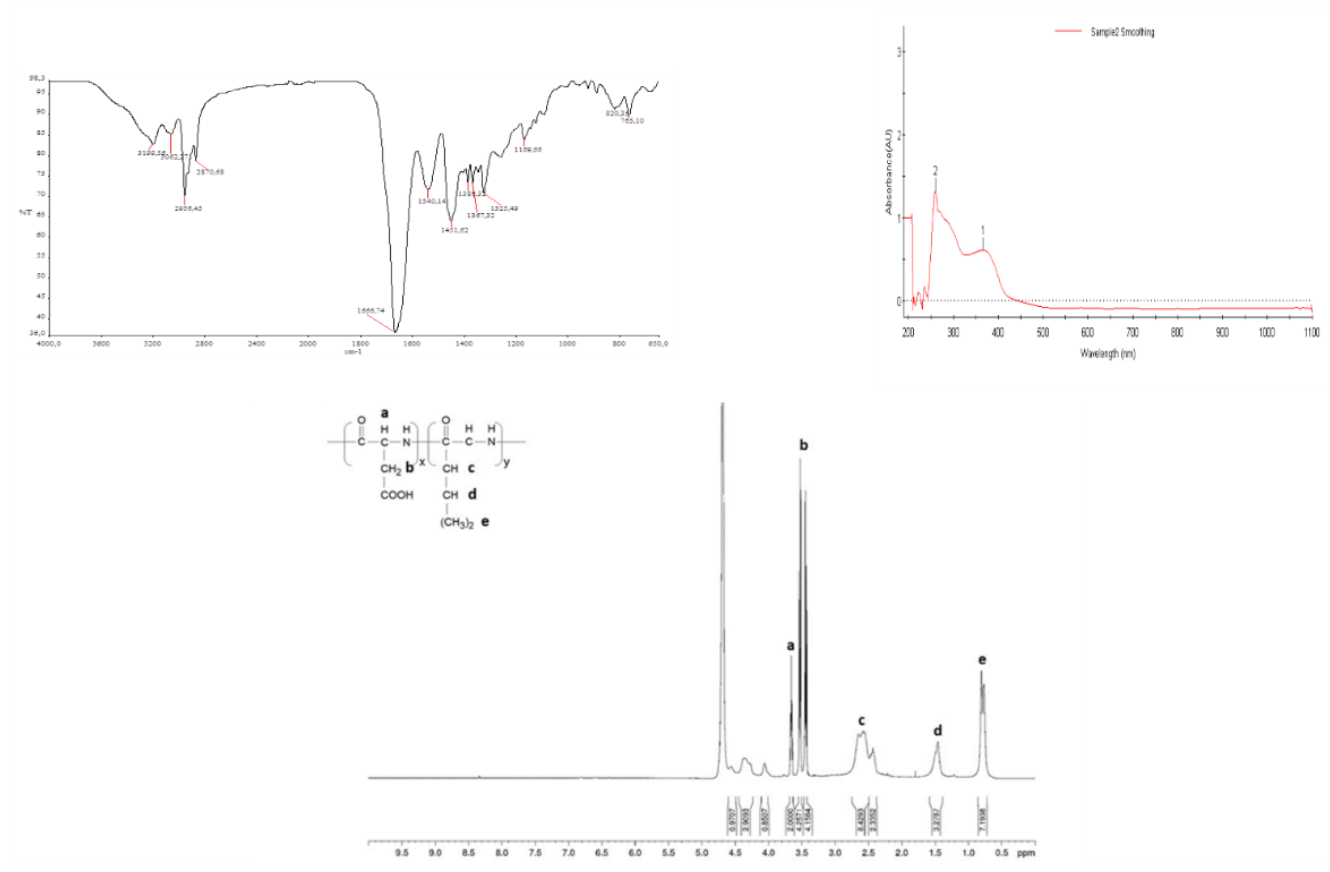

Şekil 1. Proteinoidlerin FT-IR, H-NMR ve Uv-Vis Spektrumları

\section{B. Proteinoidlerin Mikroskop Görüntüleri}

Proteinoidlerin 1ş1k mikroskobunda 20x büyütme ile görüntülerine bakılarak su da kapsüle olup olmadıklarına bakılmıştır. Şekil 2' de görüldüğü gibi başarılı şekilde sonuca ulaşılmıştır. Proteinoidlerin CD-138 olan etiket boyası ile boyanarak alınan floresan mikroskop 50x büyütme görüntüleri alınmıştır. Üçüncü olarak da SEM mikroskopta $30 \mu \mathrm{m}$ skalada kuru örnekten görüntü alınmıştır. Proteinoidler su gibi polar ortamda kapsüle olduğu ve kuru ortamda ise bu yapının bozulduğu görülmüştür (Şekil 2).
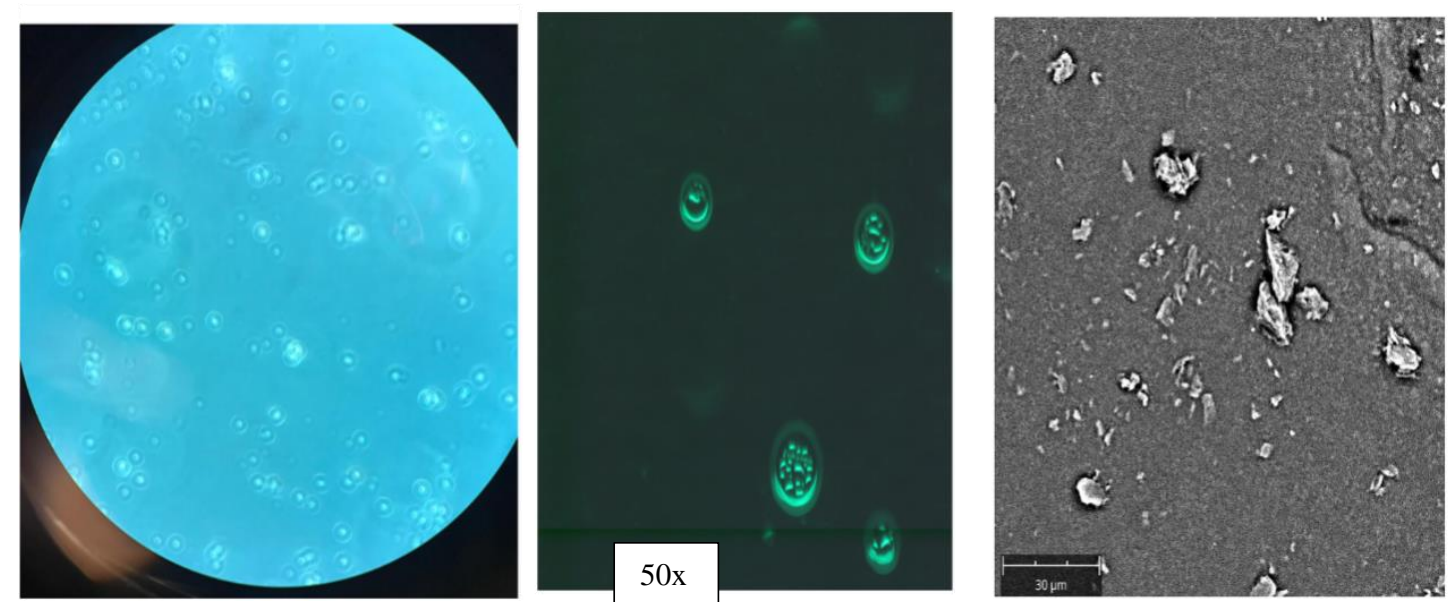

Şekil 2. Proteinoidlerin 20x 1şık, 50x floresans ve SEM mikroskop görüntüleri

\section{Proteinoidlerin Cyclic Voltammetry (CV) Grafiği}

Bazik ve asidik proteinoidlerin elektriksel hareketleri, elektrik yüklerine ve bu proteinoidlerin taşıdığ amino asitlerin yüklerine bağlı olarak birbirleri arasında farklılık göstermiştir. Kontrol olarak ham aminoasitler kullanılmıştır. Bundan dolayı proteinoid ve başlangıç bileşikleri olan aminoasitlerin elektriksel potansiyelleri karşılaştırılmalı olarak incelenmiş ve anlamlı farklılıklar görülmüştür (Şekil 3). 


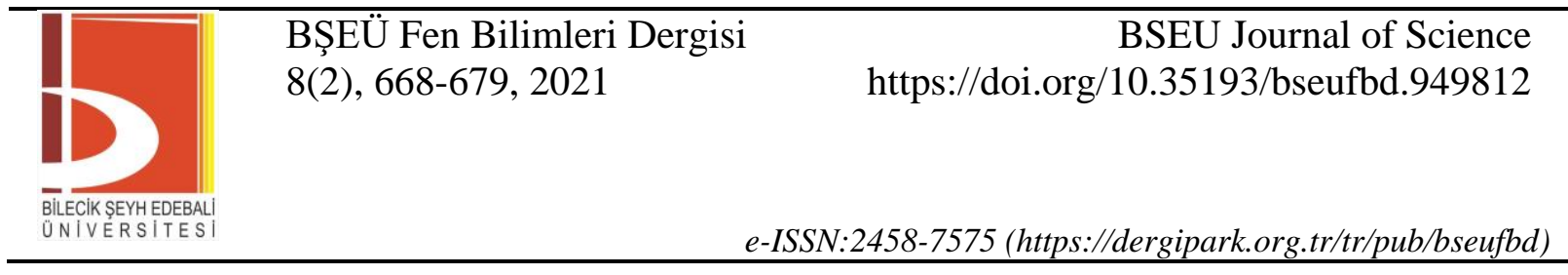

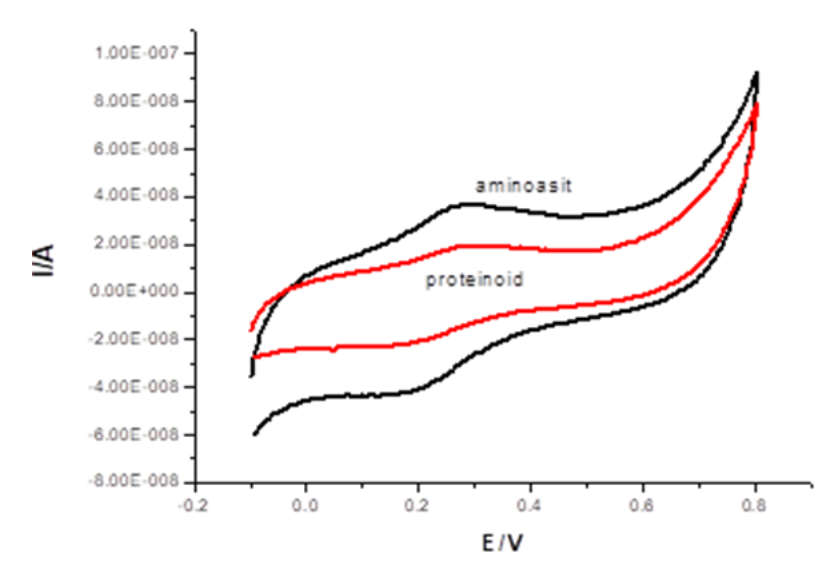

Şekil 3. Proteinoidlerin cyclic voltammetry (cv) grafiği

\section{Proteinoidlerin Bradford Protein Belirleme Grafĭği}

Proteinoidler en kısa tanımıyla ilkel proteindirler. Yüksek sıcaklı̆ga maruz bırakılmış amino asitlerden oluşan bir grup sentetik, protein benzeri polimerden herhangi biridir. Proteinoidler protein tabanlı oldukları için protein miktarlarına bakılmıştır (Şekil 4). Burada sentezlediğimiz proteinoidin kütlesel miktarı 0,450 mg/ml olarak bulunmuştur.

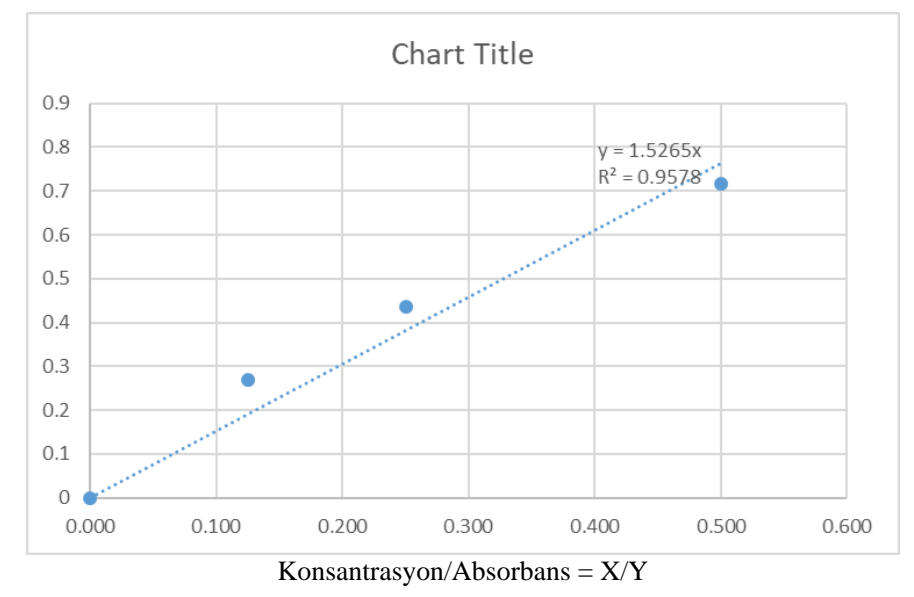

Şekil 4. Proteinoidlerin Bradford protein belirleme grafiği

\section{E. Proteinoidlerin Jel Geçirgenlik Kromatografi İle Molekül Ağırlık Grafiği}

Jel geçirgenlik kromatografisi, bir maddenin parmak izi olan molakül ağırlı̆̆ının bulunması için bu çalışma da kullanılmıştır. Proteinoidlerin molekül ağırlığı aralığı 100-450,000 Da arasındadır. Bu çalışma için sentezlenen proteinoidin molekül ağırlı̆̆ı (312 dalton) bulunmuştur (Şekil 5).

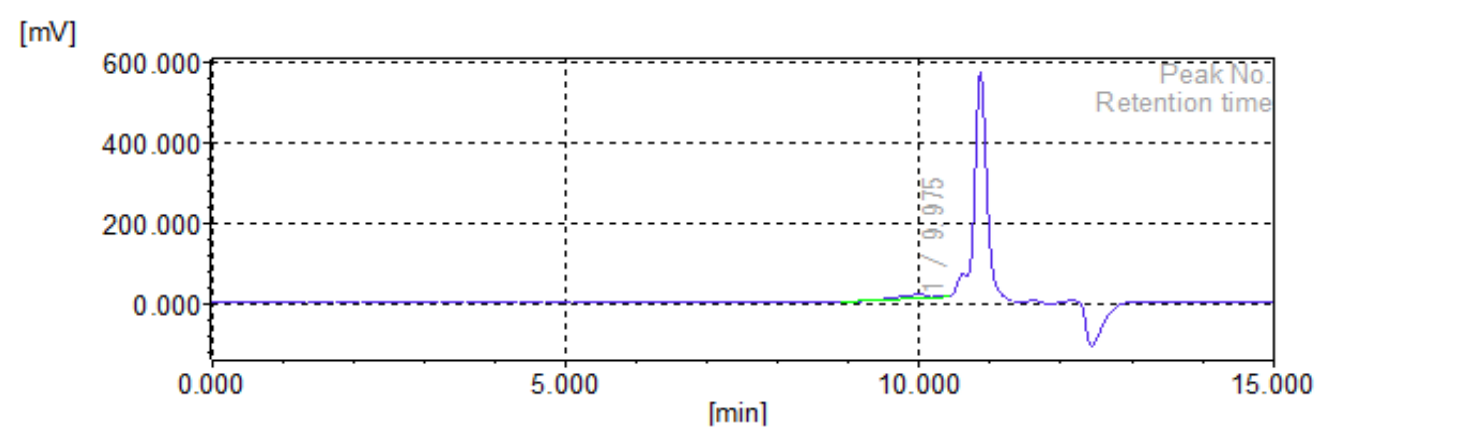

Şekil 5. Proteinoidlerin jel geçirgenlik kromatografi ile molekül ağılık grafiği 


\begin{tabular}{|c|c|c|}
\hline & $\begin{array}{l}\text { BŞEÜ Fen Bilimleri Dergisi } \\
8(2), 668-679,2021\end{array}$ & $\begin{array}{r}\text { BSEU Journal of Science } \\
\text { https://doi.org/10.35193/bseufbd.949812 }\end{array}$ \\
\hline $\begin{array}{l}\text { CIKSEYHEDEBALI } \\
\text { IVERSITESI }\end{array}$ & & 2458-7575 (https://dergipark.org.tr/tr/pub/bseufbd) \\
\hline
\end{tabular}

\section{F. Proteinoidlerin Hücre Canlılı̆̆ına Etkisi}

Proteinoidler kanser hücre hattında (Mda-mb-231 hücre hattı) ve kontrol olarak sağlıklı hücre olarak (L929 fibroblast hücre hattı) uygulanan hücre canlılığına olan etkileri farklı derişimlerinde MTT testi ile \% canlılık kontrolü yapılmıştır. Normal hücrelerde anlamlı bir etki göstermezken kanser hücresinde $50 \mu \mathrm{g} / \mathrm{ml}$ da $\% 50$ den az canlılık görülmüştür $(* * * * \mathrm{P}<0.001)$ (Şekil 6).

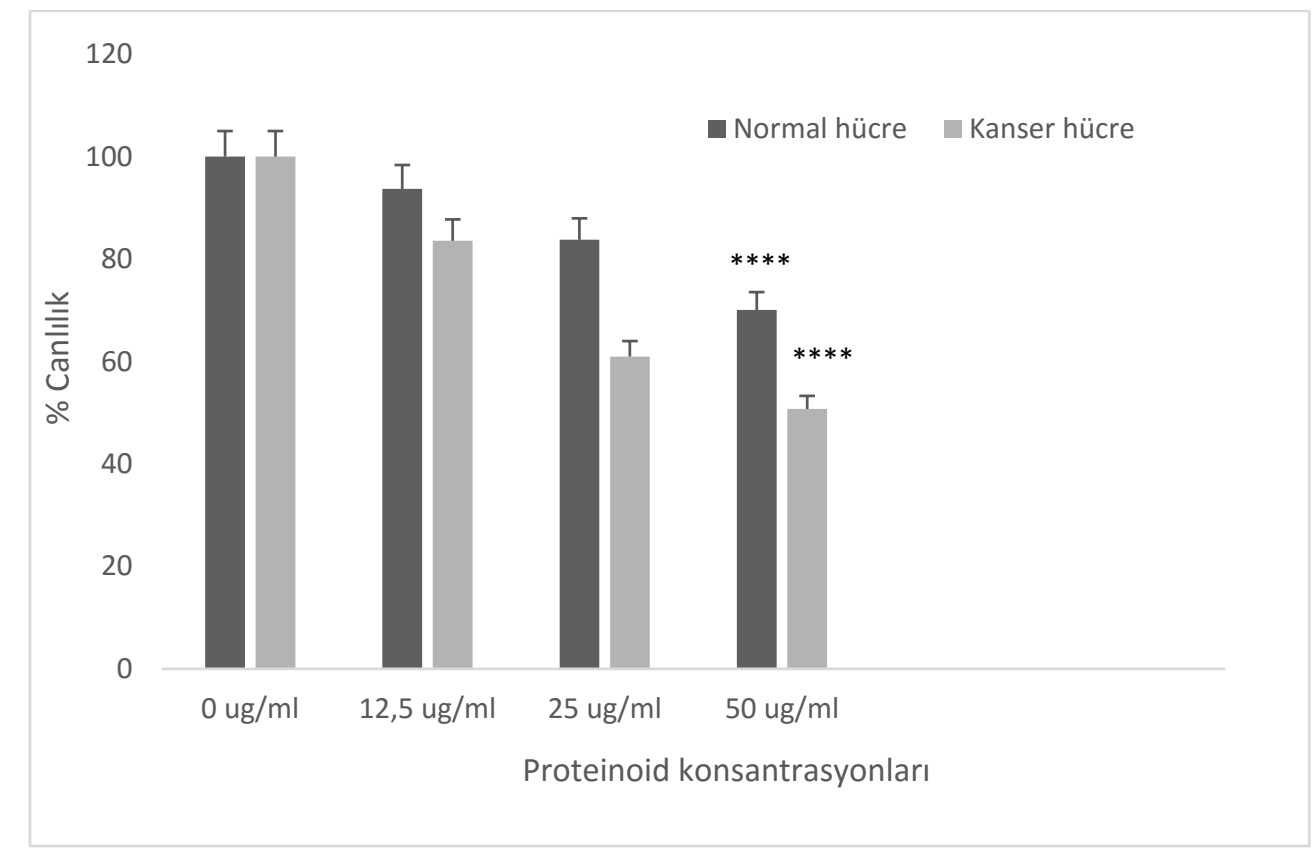

Şekil 6. Proteinoidlerin \% canlılık testi grafiği

\section{G. Proteinoidlerin Kăğt Disk A Ăar Difüzyon Yöntemi}

Antimikrobiyal madde etkinliğinin (AMM)'nin (özellikle antibiyotik vs.) etkinliği bu yöntemle kısa sürede ortaya konulabilir. Yöntem; BL21 ve ER2508 E-coli bakteri suşları ile aşılanmış petri kutusundaki besiyerine eklenen AMM'nin, besiyerinde difüze olduğu alanda BL21 ve ER2508 E.coli bakteri suşlarının gelişimini engelleyip engellemediğinin belirlenmesine dayanmaktadır. Proteinoidler mikroorganizmalar üzerinde etkiliyse; proteinoidler'in eklendiği yerin çevresinde, inkübasyon sonrasında mikroorganizma gelişiminin gözlenmediği bir "inhibisyon zonu" oluşur. Etkili degilse inhibisyon zonu oluşmaz ve AMM etkiliğinin olmadığına karar verilir. Bu çalışmada "kağıt disk ağar difüzyon" yöntemi uygulandı ve inhibisyon zonu oluşmadı. Proteinoidlerin antibakteriyel aktivite göstermediği sonucuna ulaşıldı (Şekil. 7). Petri kutusu, inkübasyon sonrasında disklerin çevresi incelemeye alındı. İnhibisyon zonlan inkübasyonun 24. ve 48. saatlerinde ayrı ayrı incelemeye alınarak değerlendirildi. Şekil 7 da yapılan deneyde inhibisyon zonlan inkübasyonun 24. ve 48 . saatlerinde ayrı ayrı incelenmiş zon oluşmadığı görülmüştür. Kontrol amaçlı olarak yapılan deneyde iki plate hazırlanmıştır. Birinin ağarına proteinoid sürülerek iki ecoli bakterisi (BL21 ve ER2508 E.coli bakteri suşları) çizgi çizgi ekilmiştir. Diğer plate proteinoid sürülmeyerek yine aynı iki bakteri aynı şekilde ekilmiştir. Her iki plate de bakterilerin çoğaldığı gözlenmiştir. Bunun sonucunda proteinoidler antimikrobiyal madde olmadığı görülmüştür. Biyolojik tanıma elemanı olarak proteinoidlerin bakterilerde kullanılacağı kanısına varılmıştır. 


\begin{tabular}{|c|c|c|}
\hline & $\begin{array}{l}\text { BŞEÜ Fen Bilimleri Dergisi } \\
8(2), 668-679,2021\end{array}$ & $\begin{array}{r}\text { BSEU Journal of Science } \\
\text { https://doi.org/10.35193/bseufbd.949812 }\end{array}$ \\
\hline $\begin{array}{l}\text { BIILCEC SEEYHEDEBALI } \\
\text { UNIVERSITES }\end{array}$ & & 2458-7575 (https://dergipark.org.tr/tr/pub/bseufbd) \\
\hline
\end{tabular}
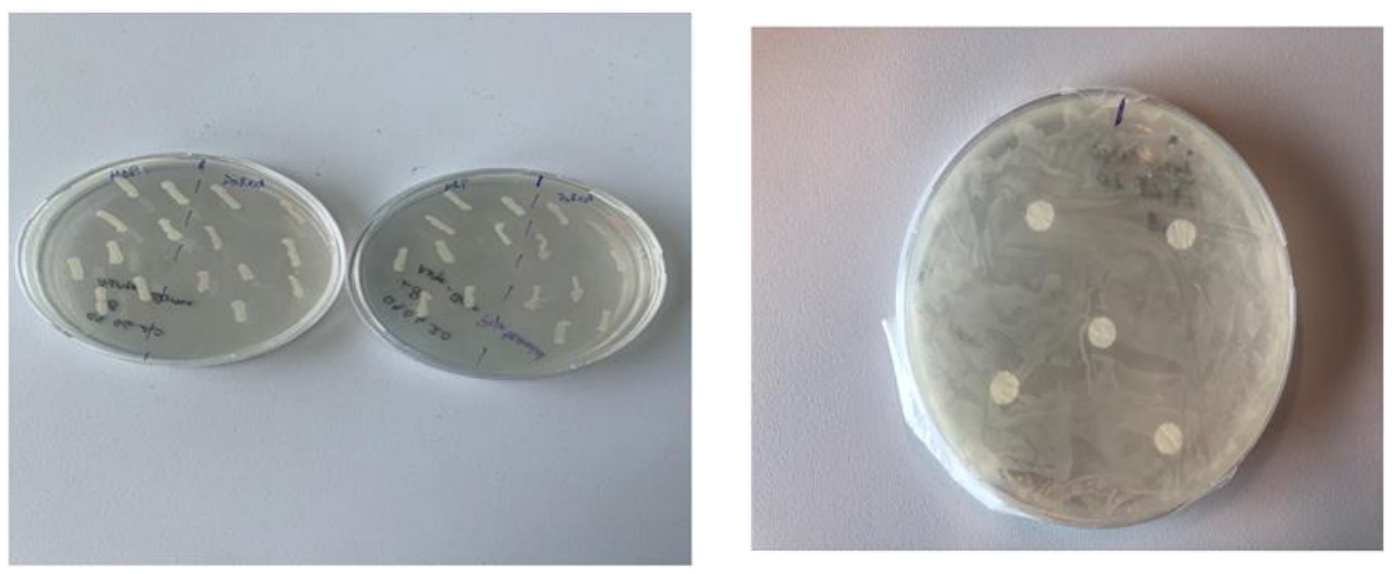

Şekil 7. Kağıt disk ağar difüzyon yöntemi

\section{H. Empedans Spektroskopi Ölçümleri}

Yapılan ölçümlerde farklı proteinoid değişimleri olduğu gibi, aynı proteinoid derişimi içinde farklı bakteri sayılarına sahip örneklerin empedans ölçümleri yapılmış olup alınan frekansa bağlı empedans değişim analizleri yapılmıştır. $50 \mu \mathrm{g} / \mathrm{ml}$ proteinoid IZI $=46 \Omega$ ve faz $(\phi)=87.6 \mathrm{iken} 100 \mu \mathrm{g} / \mathrm{ml}$ preoteinoid IZI $=50 \Omega$ ve faz $(\phi)$ $=87.6$ dır. Empedans artar iken voltaj etkinliğinde düşüş görülmüşsür. Proteinoid derişiminin artması rezesif etkiyi artırıp fazda $(\phi)$ herhangi bir değişime neden olmamıştır (Şekil 8).

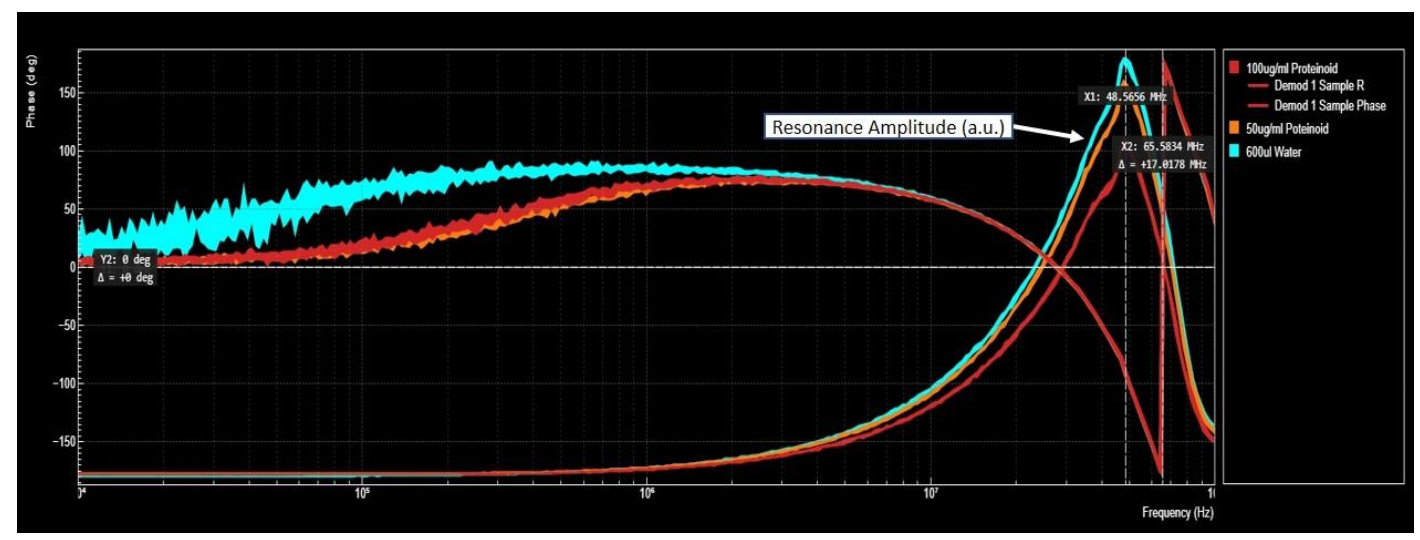

Şekil 8. Proteinoidin empedans spektrumu

Öncelikli olarak empedans ölçüm aralığı $10 \mathrm{kHz}$ ile $80 \mathrm{MHz}$ arasında yapılmıştır. Empedans ölçümleri sadece distile su, sadece bakterilerin yetişmesi için kullanılan besiyeri, sadece bakteri ve 1-4 saat arası çoğalmaları sağlanan ecoli bakterilerinin proteinoidle karıştırılmış örnekleri ayrı ayrı empedans-frekans bağımlılıkları ölçülmüştür. Alınan örneklemde distile su, besiyeri ve sadece proteinoid çözeltisi ölçümleri referans alınarak empedanstaki faz değişimin 180 derece değiştiği görülmüştür. Değişimin olduğu noktada faz geçişinin belli proteinoid derişimlerinde bakteriler ile karıştırıldıktan sonra empedans faz geçişinin bakteri üremesine bağlı olarak lineer değiştiği gözlenmiştir. Şekil 8'da $500 \mu \mathrm{l}$ 'lik $100 \mu \mathrm{g} / \mathrm{ml}$ proteinoid ve belli saatte çoğalması sağlanmış bakteri ortamından $500 \mu \mathrm{l}$ karıştırılarak toplamda $1000 \mu \mathrm{l}$ olan örneklerin empedans değişimleri gösterilmektedir. Proteinoid + E.coli bakterilerinin empedans değerleri distile su ve besiyerinden daha yüksek değerlere çıktığg Şekil 8'de gösterilen voltaj düşüşünden çıkarmak mümkündür. 


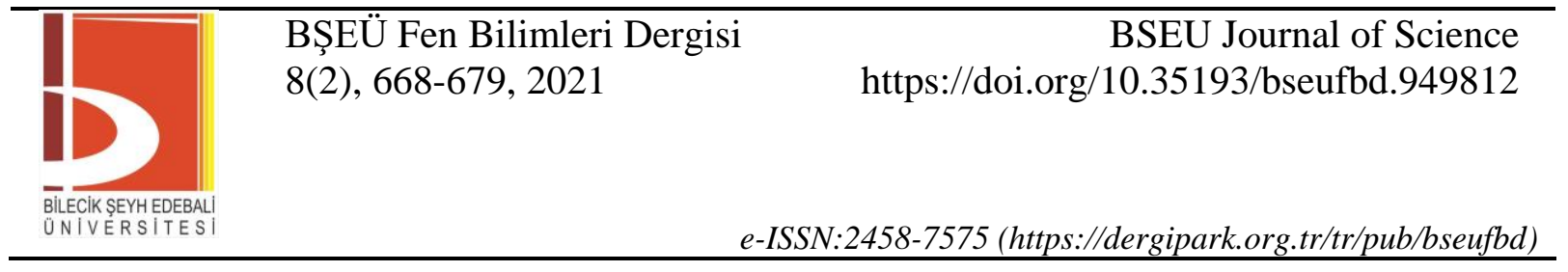

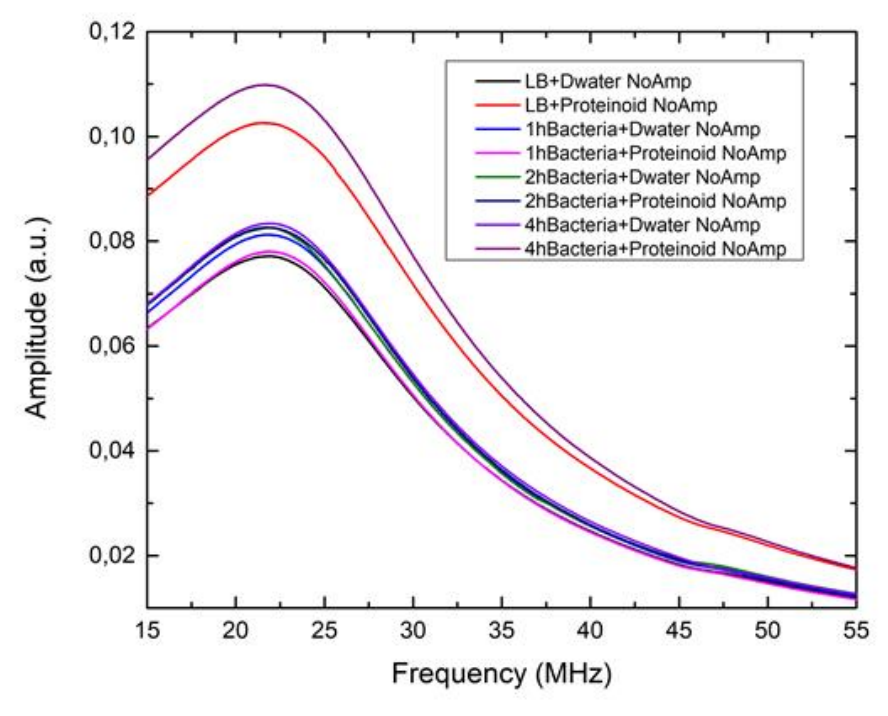

Şekil 9. 15MHz-55MHz arası frekanslarda göreceli empedans değişimi

Şekil 9'da bakterilerin relatif empedansda gözle görülür bir değişiklik yaptığı fakat öncül deneylerde empedans büyüklüğünün bakteri yoğunluğuyla arasında net bir ilişki olmadığı gözlemlenmiştir. Şekil 10'da empedansın frekans bağımlığı örnekleri empadanslarının faz değişimlerine bakılarak analiz edildiği gösterilmektedir. $30 \mathrm{MHz}$ frekansı civarlarında empedans fazda 180 derece geçişte ayırt edilebilir ve ilişkilendirilebilir bir faz kayması görülmektedir.

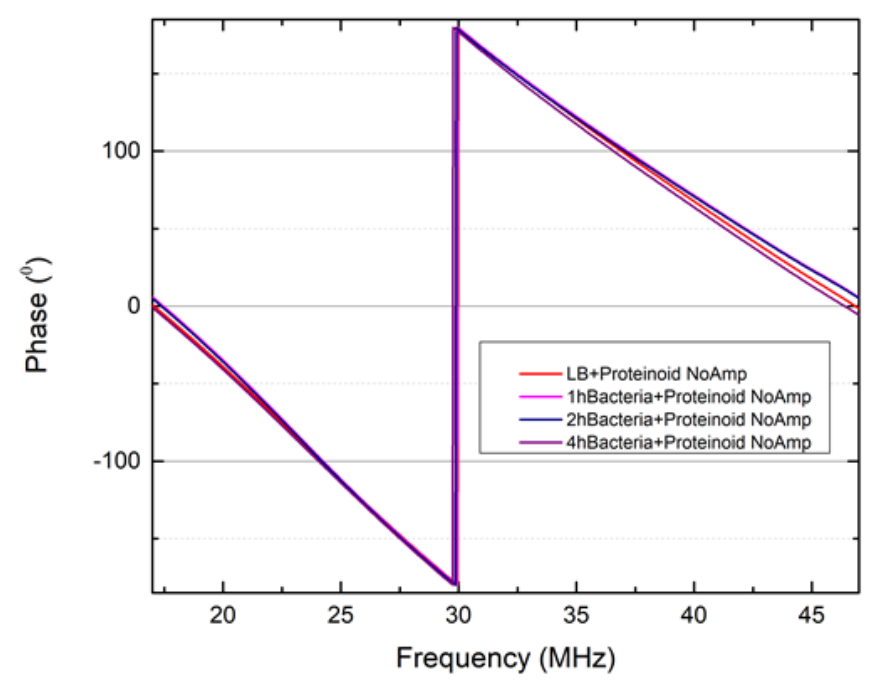

Şekil 10. Empedans Fazı- Frekans grafiği

Faz geçişindeki bu kayma Şekil 10'da gözlenen faz kayması, proteinoid+ecoli örneklerinde belli bir örüntüye işaret etmektedir. 


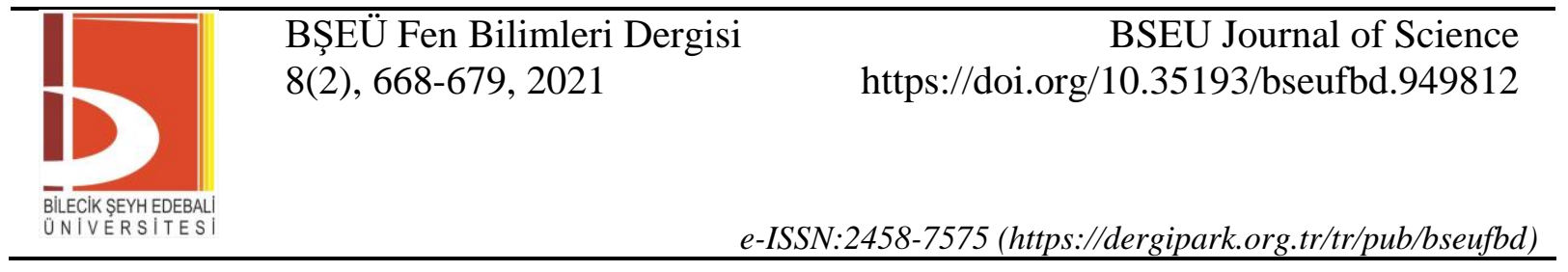

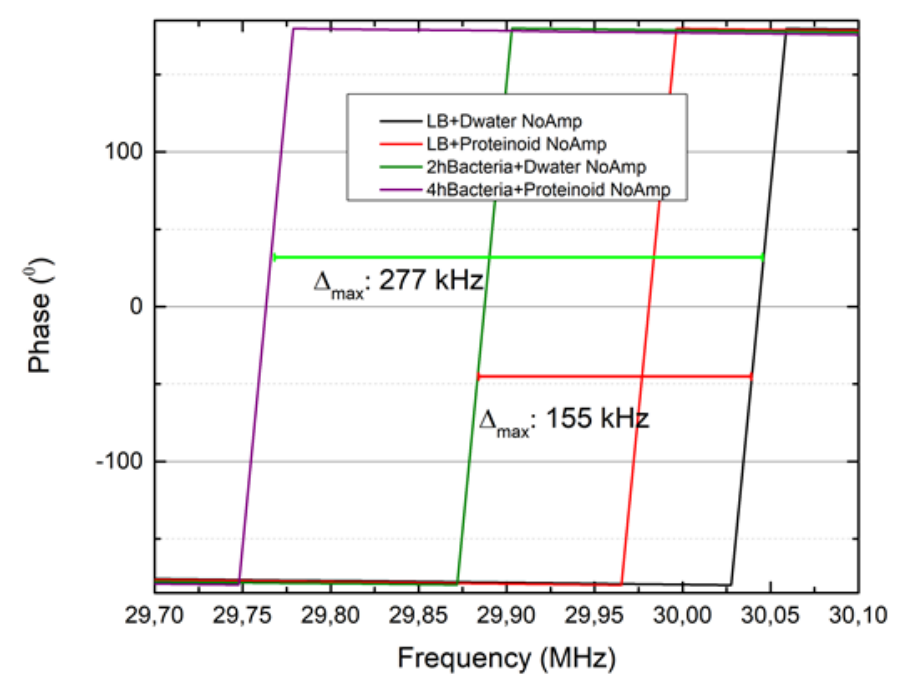

Şekil 11. Faz değişimdeki kaymaların karşılaştırması

$30 \mathrm{MHz}$ mertebelerindeki kaymalar 100-300 kHz mertebelerinde olup, elektronik algılama açısından rahatlıkla ayırt edilebilir bir bant aralığındadır. Proteinodlerin empedansda bu kaymaları sıralı hale getirebileceği ve kayma miktarlarında bir yükletmeye ve daha düşük frekanslara kayabildiği gözlemlenmiştir (Şekil 11). Yapılan çalışmaların devamında bu kayma mikraları düşük frekanslara doğru kayma ve bu kaymanın proteinoidler tarafından artırılması üzerine optimizasyon çalışmaları yapılmışıı. Proteinoidlerin bakteri algılaması sonucunda farklı frekanslarda sinyal vermiştir.

\section{I. İstatiksel Analiz}

İkiden fazla parametrik değişkenin karşılaştırılması Tek Yönlü Varyans Analizi (ANOVA) ile, Sidak Çoklu Karşılaştırma Testi ise post hoc testi ile yapılmıştır. Tüm istatistiksel analizler $\% 5$ anlamlılık düzeyinde yapıldı ve $\mathrm{P}<0.05, \mathrm{P}<0.01$ ve $\mathrm{P}<0.001$ istatistiksel olarak anlamlı kabul edildi. Analiz, Graphpad Instat (GraphPad Software, San Diego, CA, ABD) kullanılarak gerçekleştirildi. Kanser hücresinde proteinoid $50 \mu \mathrm{g} / \mathrm{ml}$ ****p $<0.001$ vs diğer bütün gruplar, Normal hücresinde proteinoid $50 \mu \mathrm{g} / \mathrm{ml} * * * * \mathrm{P}<0,001$ vs diğer gruplar (Şekil 6 )

\section{SONUÇLAR}

Bu çalışmada bakterin tespit edilmesi için yeni bir biyolojik tanıma elemanı kullanılmıştır. Kullanılan bu biyolojik tanıma elemanı olan proteinoid sentezlenip karakterize edilmiştir. Hedef organizmaya (analit) duyarlılı̆̆ olan molekül seçimi; biyolojik tanıma elemanı, biyoduyarganın özgünlüğünü belirlediği için hayati bir rol oynar. Moleküler biyoduyargaların en önemli özellikleri yüksek seçicilik ve afinitedir. Proteinoidler (termal proteinler) kullanılan biyolojik tanıma elemanları içinde afinitesi ve seçiciliği en yüksek olanlardan biridir. Çünkü bazik ve asidik karakterli proteinoidlerin elektrik yüklerine ve bu proteinoidlerin taşıdığı amino asitlerin yüklerine bağlı olarak hedef organizma ile anahtar- kilit modellerinden dolayı biyolojik uyumlulukları, ve toksik olmamaları nedeniyle birçok alanda kullanılmasını sağlamıştır [19]. Bu sebeple bu çalışmada biyolojik uyumlulukları yüksek olan proteinoidler biyotanıma elemanı olarak kullanılmıştır. Proteinoidler en kısa tanımıyla ilkel proteinlerdir. Yüksek sıcaklığa maruz bırakılmış amino asitlerden oluşan bir grup sentetik, protein benzeri polimerden herhangi biridir. Proteinoidler birçok aktiviteye sahiptir. Esteroliz, dekarboksilasyon, aminasyon, deaminasyon ve oksidoredüksiyon gibi katabolik enzim aktiviteleri bunların başında gelir. Ek aktivitelerinden bazı özellikleri ise hormonal ve inhibe edicidir. ATP, peptidler veya oligonükleotitlerin oluşumu sentetik enzim aktiviteleridir [20]. Özetle birçok biyokimyasal aktiviteye sahip proteinoidler aynı anda bir hormon gibi ya da bir enzim veya bir antikor gibi davranabilir. Bu şekilde davranabilme özellikleri diğer biyolojik tanıma elemanlarının (proteinler, aptamer, nükleik asit, bakteriler, metal iyonları, peptidler, enzimler ve antikorlar) içinde kendisine yüksek afinite ve seçicilik katmaktadır.

Seçilen molekülün ekonomik olarak fizibilitesine bakıldığında; proteiniodlerin sentezlenme yöntemleri diğer biyolojik tanıma elamanlarına göre çok daha kolay ve ucuz olması, bu bileşikleri daha cazip kılmaktadır. Proteinoid oluşumu ise, herhangi çözücü ve katalizör kullanılmaksızın proteinoidlerin kendi aktivitesidir ve termal 
polimerizasyon sonucu rastgele oluşmaktadır [21]. Diğer biyolojik tanıma elemanlarından peptid ile karşılaştıracak olursak 3 sekanslık bir amino asit zincirinden peptileri sentezlemek yüksek maliyetler gerekmektedir. Alnnacak aminoasitler bile proteinoidte kullanılan aminoasitler gibi değildir yan zincirleri herhangi reaksiyona girmemesi için bloklanmıştır. Bu bloklanma aminoasitlere yüksek maliyet katmaktadır. Peptid sentezleri için bu aminoasitlerdeki blokları kaldırmak için çözücü ve katalizörde kullanılarak maliyet gittikçe katlanmaktadır.

Birbiri ile etkileşime geçtiği takdirde (bakteri ve proteinoid) logaritmik olarak hangi fiziksel değişiklikler oluşuyor? Proteinoid sentezlenip karakterize edildikten sonra öncelikle bu soruyu sorduk. Örneğin: Uv grafik , Empedans grafik vb.; Proteinoidin hedef analite bağlanması ile analitin konsantrasyonuyla orantılı sinyaller üreterek hangi biyolojik veya kimyasal reaksiyonlar vermektedir. Biyoduyargaların geliştirilmesinde çok çeşitli teknikler kullanılabilir. Biyoduyargaların yüksek afiniteli biyomoleküllerle birleşmeleri bir dizi analitin hassas ve seçici bir şekilde algılanmasını sağlar. Biyomolekülün (proteinoid) analitle (bakteri vb.) etkileşimi üzerine sinyal üretme işlemi (1şık, 1sı, pH, elektrik yük veya kütle değişimi vb.) şeklinde biyotanıma olarak adlandırılır. Isı ışık ve elektrik yük olarak dönüştürülen sinyali işleyen ve gösterime hazırlayan biyoduyarganın diğer kısmı elektroniktir. Proteinoidin iletkenliği 1266 mikrosimens olduğundan bu referans alınarak proteinoid ile bakterilerin birleşmesindeki elektrik yük değişikliğinden empedans ölçümleri ile bakteriler tespit edilmiştir. Tespit başarımı tekrarlı olarak hedef başarım aralığı yakalanıncaya kadar karakterize eden işaret işlemi ve algoritması arasından uygunluk sağlamak üzere iyileştirmeler yapılıp istenilen sonuca varılmıştır. İleriki araştırmalarımızda ki hedeflerimiz; proteinoidlerin farklı patojenler ile çalışmalarımız devam edecektir. Jel matriks ile çalışma koşullarından dolayı çok küçük plakaların kullanılması mümkün olmamıştır. Bu nedenle, daha sağlıklı sonuçlar alınabilmesi için bir mikroakışkan çip sistemi tasarımı yapılıp, bundan sonraki ölçümler bu sistemde alınacaktır.

\section{KAYNAKLAR}

[1] Bilal, M. \& Iqbal, H. (2019). Microbial-derived biosensors for monitoring environmental contaminants: Recent advances and future outlook. Process Safety and Environment Protection, 90,1-5

[2] Dincer, C., Bruch, R., Costa-Rama, E., Fernández-Abedul, M. T., Merkoçi, A., Manz, A., Urban, G. A. \& Güder, F. (2015). Disposable Sensors in Diagnostics, Food, and Environmental Monitoring. Advanced Materials, 1806739

[3] Gavrilescu, M., Demnerova, K., Aamand, J., Agathos, S. \& Fava, F.(2015). Emerging pollutants in the environment: present and future challenges in biomonitoring, ecological risks and bioremediation, New Biotechnology, 32, 1.

[4] Chae, M. S., Yoo, Y. K., Kim, J., Kim, T. G. \& Hwang, K. S. (2018). Graphene-based enzyme-modified field-effect transistor biosensor for monitoring drug effects in Alzheimer's disease treatment. Sensors \& Actuators: B. Chemical, 272, 448-458

[5] Dincer, C., Bruch, R., Costa-Rama, E., Fernández-Abedul, M. T., Merkoçi, A., Manz, A., Urban, G. A. \& Güder, F. (2019). Disposable Sensors in Diagnostics, Food, and Environmental Monitoring. Advanced Materials, 1806739

[6] Cesewski, E. \& Johnson, B. N. (2020). Electrochemical biosensors for pathogen detection. Biosensors and Bioelectronics, 159, 112214

[7] Zhenguo, Z., Jun, Z. \& Xin, D. (2019). Electrochemical Biosensors for Detection of Foodborne Pathogens. Micromachines, MDPI, 10, 222

[8] Bhalla, N., Jolly, P., Formisano, N. \& Estrela, P. (2016). Introduction to biosensors. Essays in Biochemistry, $60,1-8$

[9] Nakashima, T. \& Fox, S. W. (1980). Synthesis of Peptides from Amino Acids and ATP with Lysine-Rich Proteinoid. Journal of Molecular Evolution, 15, 161-168

[10] Lugasi, L., Grinberg, I. \& Margel, S. (2020). Targeted Delivery of CBD-Loaded Poly (RGD) Proteinoid Nanoparticles for Antitumor Therapy, Journal of Nanomed Nanotechonology, 11(6), 552.

[11] Kumar, A. B. M., Jayakumar, R. \& Rao, K. P. (1996). Synthesis and Aggregational Behavior of Acidic Proteinoid, Journal of Polymer Science: Part A: Polymer Chemistry, 34, 2915-2924

[12] Sasson, E., Ruth, V., Margel, S. \& Klipcan, L. (2020). Engineering and use of proteinoid polymers and nanocapsules containing agrochemicals. Scientific RepoRtS Nature, 10, 9171

[13] Tallawi, M. (2010). Proteinoid/hydroxyapatite hybrid microsphere composites' Wiley Periodicals.

[14] Hadad, E. Rudnick-Glick, S. Grinberg, I. Yehuda, R. \& Margel, S. (2020). Engineering of NIR fluorescent PEGylated poly(RGD) proteinoid polymers and nanoparticles for drug delivery applications in chicken embryo and mouse models', Royal Society of Chemistry, 10, 34364 
[15] Matsuno, K. (1982). Natural self-organization of polynucleotides and polypeptides in protobiogenesis: Appearance of a protohypercycle, BioSystems, 15, 1-11

[16] Kolitz - Domb, M., \& Margel, S. (2018). Recent Advances of Novel Proteinoids and Proteinoid Nanoparticles and Their Applications in Biomedicine and Industrial Uses, Israel Journal Chemistry, 58, 1277.

[17] Madhan, K. A. B., \& Panduranga, R. (1998). Preparation and characterization of pH-sensitive proteinoid microspheres for the oral delivery of methotrexate. Biomaterials, 19, 725-732

[18] Kwon, K., Park, D., \& Kim, J. C. (2019). Disulfide proteinoid micelles responsive to reduction, Journal of Dispersion Science and Technology, 40(10), 1413-1422

[19] Lugasi, L. Grinberg, I. Rudnick-Glick, S. Okun, E. Einat, H., \& Margel, S. (2020). Designed proteinoid polymers and nanoparticles encapsulating risperidone for enhanced antipsychotic activity. Journal of Nanobiotechnol, 18, 149

[20] Madhan, K. A. Jayakumar, R., \& Panduranca, K. R. (1996). Synthesis and Aggregational Behavior of Acidic Proteinoid, Journal of Polymer Science: Part A: Polymer Chemistry, 34, 2915-2924

[21] Kumar, A. B. M. \& Rao, K. P. (1998). Preparation and characterization of pH-sensitive proteinoid microspheres for the oral delivery of methotrexate", Biomaterials, 19, 725-732 